1917

ग293

I avis

Factors Influencing the Keeping Qualities of Apples in Cold Storage 



\title{
FACTORS INFLUENCING THE KEEPING QUALITIES OF APPLES IN COLD STORAGE
}

\author{
PHILIP FRANK DAVIS
}

\section{THESIS}

Submitted in Partial Fulfillment of the Requirements for the

$$
\text { Degree of }
$$

\section{BACHELOR OF SCIENCE}

IN HORTICULTURE

IN

THE COLLEGE OF AGRICULTURE

OF THE

UNIVERSITY OF ILLINOIS 
1917
1793

\section{UNIVERSITY OF ILLINOIS}

May 31 191.......

THIS IS TO CERTIFY THAT THE THESIS PREPARED UNDER MY SUPERVISION BY Philip Frank Davis

ENTITLED Foctors Influencing the Keeping Qualities of Apple.s in Cold stor. stoge

IS APPROVED BY ME AS FULFILLING THIS PART OF THE REQUIREMENTS FOR THE DEGREE OF. Bachelor of Science in Horticulture
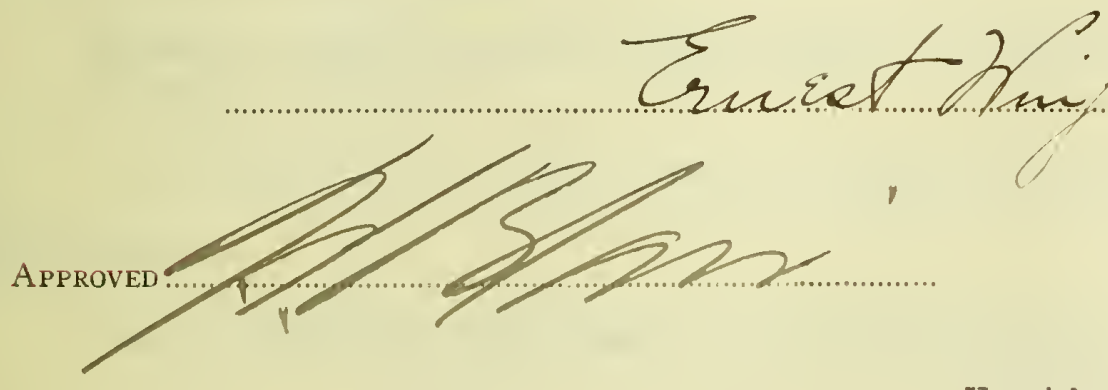

HEAD OF DEPARTMENT OF Horticheriture 

CONTENTS.

\section{Pages}

Introduction.

The importance of cold storage in apple marketing.

Body.

The way in which cold preserves fruit.

The effect of different storage temperatures.

The necessity of cleanliness in a storage.

Variation in keeping qualities with different

varieties of apples.

Variation in keeping qualities with fruit from under different conditions.

The importance of proper maturity in fruit for storage.

The importance of care in the handing of apples for storage.

The effect of the type of package upon the keeping qualities of apples

The effect of wrappers upon the keeping gualities

of apples.

The effect of delay in storage of apples upon their keeping qualities

Factors affecting the development of scald on storage apples.

The behavior of apples after removal from storage. ¿6-2'?

Conclusion.

The increaging importance of cola storage. 


\section{Digitized by the Internet Archive in 2013}


Factors Influencing the Keeping qualities of Apples in Cold storage. 



\section{FACTORS INFLUENCING THE KEEPING QUALITITS OF APPIES IN COID STORAGE.}

One of the most important factors in the rapid rise of American fruit growing has been the application of the principles of refrigeration to warchouses. One of the chief problems which makes apple growing a doubtful occupation is the instability of the market. Often, when a good crop is secured throughout the country, or even when there is a good crop in only one section with fair yields in the others, the apples in the sections of heavy yielc are hardy worth harvesting.

Mr. Roy D. Antony $(20, a)$ * of New York (Geneva) Experiment station gives the cost of producing a barrel of apples as \$1.48. He states that where better management is used, this can be reduced to $\$ 1.21$. Allowing \$0.50 per barrel for freight and commission charges (which is low, as vilkingon $(20, a)$ allows \$0.22 per bushel for this when New York growers place their fruit on the New York market), the cost of putting a barrel of apples onto the market would range from 1.71 to $\$ 1.98$. Table I (after Wilkinson) gives the yearly average price per barrel received for apples on the New York market, the table coverine a period of twenty years.

bibliography.

* $(20, a)$ refers to a corresponaing number in the 

Table I.

Average Price of Apples in New York for Twenty Years.

Year

lotal receipts

(barrels)

Averate Price per barrel

$1893-1894$

$1894-1895$

$1895-1896$

$1896-1897$

$1897-1898$

$1898-1899$

$1899-1900$

$1900-1901$

$1901-1902$

$1902-1903$
$2: 34,863$

$5: 36,338$

736,487

$1,426,546$

877,077

650,686

921,648

895,967

593,816

$1,540,005$
$\$ 3.43$

2.60

2.21

1.41

2.66

3.25

2.33

2.50

2.72

2.08
$\$ 2.62$

2.39

2.09

3.30

2.64

3.05

3.22

3.18

3.57

2.68

$\$ 2.87$
$1908-1909$

$1909-1910$

1910-1911

1911-1912

$1903-1904$

1911-1912
$1,898,268$

$1,932,327$

$1,875,168$

$2,043,506$
$1,865,459$

$1,566,855$

$1,687.719$

$1,875,168$

Subtracting the cost is given above, from the iver York average prices for the last ten years given in this table, shows a profit of from $\$ 0.89$ to $\$ 1.16$ per barrel.

Let us turn to Table II taken from the $191 \mathrm{~b}$ yearbook of the Departnent of Agriculture (2I). These figures are estinates by the Bureau of Crop Estimates. 

Table II

Production and Farm Price per Bushel for Apples, 1910-1915.

\begin{tabular}{|c|c|c|c|c|c|c|c|}
\hline Year & & 1910 & 1917 & 1912 & 1913 & 1914 & 1915 \\
\hline U.S. & $\begin{array}{l}* \\
0\end{array}$ & $\begin{array}{c}47213000 \\
\$ 0.95\end{array}$ & $\begin{array}{c}71340000 \\
00.80\end{array}$ & $\begin{array}{c}78407000 \\
80.68\end{array}$ & $\begin{array}{c}48470000 \\
30.99\end{array}$ & $\begin{array}{c}84400000 \\
\$ 0.62\end{array}$ & $\begin{array}{c}76670000 \\
00.74\end{array}$ \\
\hline$I_{11} \mathrm{Y}$. & * & $\begin{array}{l}5660000 \\
\$ 1.10\end{array}$ & $\begin{array}{c}13000000 \\
40.59\end{array}$ & $\begin{array}{c}14667000 \\
\$ 0.50\end{array}$ & $\begin{array}{l}6500000 \\
0.95\end{array}$ & $\begin{array}{c}16533000 \\
0.45\end{array}$ & $\begin{array}{l}8528000 \\
\$ 0.77\end{array}$ \\
\hline Pa. & * & $\begin{array}{l}3867000 \\
\$ 0.75\end{array}$ & $\begin{array}{l}6833000 \\
0.54\end{array}$ & $\begin{array}{l}4233000 \\
0.70\end{array}$ & $\begin{array}{l}3400000 \\
0.89\end{array}$ & $\begin{array}{l}7700000 \\
\$ 0.50\end{array}$ & $\begin{array}{l}5085000 \\
\$ 0.67\end{array}$ \\
\hline$I_{n} I I$. & * & $\begin{array}{l}267000 \\
\$ 1.15\end{array}$ & $\begin{array}{l}3533000 \\
\$ 0.68\end{array}$ & $\begin{array}{l}1933000 \\
00.79\end{array}$ & $\begin{array}{l}2733000 \\
\$ 0.94\end{array}$ & $\begin{array}{l}12.33000 \\
\$ 0.84\end{array}$ & $\begin{array}{l}4716000 \\
0.55\end{array}$ \\
\hline Mich. & i & $\begin{array}{l}1400000 \\
\$ 1.02\end{array}$ & $\begin{array}{l}4100000 \\
: 0.70\end{array}$ & $\begin{array}{l}5733000 \\
\$ 0.50\end{array}$ & $\begin{array}{l}2967000 \\
\$ 0.82\end{array}$ & $\begin{array}{l}5733000 \\
0.49\end{array}$ & $\begin{array}{l}3150000 \\
\$ 0.72\end{array}$ \\
\hline
\end{tabular}

* Production in barrels of three bushels each.

- Farm price per bushel.

According to this table the yearly average prices for apples at the orchard, throughout New York state, during the years from 1910 to 1915 inclusive, have ranged from 0.45 per bushel in 1914 to 1.10 per bushel in 1910, which equals 1.35 to 3.30 per barrel. The averages for apnles at the orchard, throughout the Unted states, during this period, ranged from 0.62 per bushel in 1914 to 0.99 per bushel in 1913; this equaling 1.86 to 2.95 per barrel. Subtracting the costs of production as given by R. D. Antony, shows results ranging from a loss of 0.13 to a gain of -1.82 per barrel during this period in New York. Subtracting these costs from the Everage orchard prices throughout the country, shows a gain varying from $\$ 0.38$ to 1.76 per barrel. 

These figures look very favorable to the grower. Howevor, not all of the crop is fit for burrel stoch and it costs nearly as much to raise the poor fruit as it does the good. Estimates of commercial apple crops are given by $\operatorname{lir}$. U. J. Glasson (8,a) (8,b) in the American Year Book. His figures for commercial crops are: $31,000,000$ barrels in 1913; 50,000,000 barrels in 1914; and 40,000,000 barrels in 1915. Comparing these figures of production with the ones Given above from the United states Department of Agriculture Yearbook for 1915. for the same yturs. We find that the commercial crop was in 1913 only 64 per cent of the total crop, in 1914 only 59 per cent, and in 1915 only 52 per cent. Jart of the remainder of the fruit can of course be sola for something as evaporator ana cider stock wirere plants for the use of such fruit are available. but much of it goes to waste. An zoticle on apple by-products by $H . \checkmark$. Gore (9) in the 1914 Yearbook states that twenty-five per cent of the apples grown in America never figure in the food supply of the nation. It goes on to say, "These vaste apples are either good fruit for which the farmer can find no profitable market and therefore allows them to rot under the tree, or are surplus culls left after demands for vinegar and clder have been met." iven the fruit which is sold for these by-products brings a price much below the cost of its production.

The reason why such a Ierge part of tre crop is not worth marketing is because so much of the fruit is throw onto the market just following harvest instead of being distributed more evenIy throughout the year. Table III (after H. B. inapp) (20,b) shows the dietribution throughout the year, of apple shipments to New Yor $\mathrm{s}$, and covers a period of twenty years. 
Mable III.

Monthly and Yearly Receipts of Apples in New York City

(In Barrels)

Year Aug. Sept. Oct. Nov. Dec. Jan. Feb.

$\begin{array}{lrrrrrrr}1893-1894 & 4,632 & 20,461 & 57,068 & 66,160 & 25,678 & 18,692 & 15,462 \\ 1894-1895 & 17,046 & 33,800 & 125,000 & 159,527 & 58,419 & 33,032 & 27,942 \\ 1895-1896 & 33,510 & 75,394 & 152,419 & 164,463 & 110,638 & 50,327 & 58,782 \\ 1890-1897 & 51,947 & 188,135 & 263,491 & 273,052 & 165,494 & 115,096 & 134,113 \\ 1897-1898 & 38,713 & 11,433 & 203,538 & 196,477 & 81,695 & 70,649 & 62,560 \\ 1898-1899 & 30,428 & 76,807 & 161,876 & 117,608 & 89,251 & 49,578 & 37,323 \\ 1899-1900 & 47,918 & 102,955 & 206,216 & 185,785 & 113,277 & 75,164 & 72,156 \\ 1900-1901 & 23,116 & 82,426 & 176,411 & 189,521 & 101,193 & 99,087 & 69,548 \\ 1901-1902 & 18,379 & 53,611 & 127,191 & 106,371 & 57,021 & 51,597 & 36,013 \\ 1902-1903 & 68,007 & 154,475 & 281,936 & 255,942 & 166,971 & 130,626 & 122,687 \\ \text { Yearly average } & \end{array}$

for 10 yrs. $\quad 33,370 \quad 85,950 \quad 176,115 \quad 171,491 \quad 96,964 \quad 69,385 \quad 63,659$

$1903-1904 \quad 95,142 \quad 246,684 \quad 435,950 \quad 395,130 \quad 193,206 \quad 144,919 \quad 165,102$ $1904-1905 \quad 85,332 \quad 284,112 \quad 309,135 \quad 337,336 \quad 168,721 \quad 143,071 \quad 122,565$ $1905-1906 \quad 143,052 \quad 252,056 \quad 367,638281,482 \quad 152,945 \quad 119,309 \quad 82,084$ $1906-1907 \quad 174,637255,600 \quad 478,323 \quad 413,566 \quad 223,554 \quad 223,469 \quad 145,847$ $1907-1908 \quad 60,488 \quad 137,729 \quad 350,529 \quad 364,490 \quad 171,099 \quad 168,649 \quad 117,938$ $\begin{array}{lllllllll}1908-1909 & 121,641 & 310,289 & 447,895 & 337,580 & 217,601 & 137,683 & 92,688\end{array}$ $1909-1910 \quad 64,305 \quad 183,892 \quad 393,288 \quad 406,772 \quad 248,794 \quad 131,709 \quad 138,119$ $1910-1911 \quad 78,678 \quad 196,597 \quad 538,630 \quad 416,374 \quad 208,490127,015 \quad 115,654$ $1911-1912 \quad 75,922 \quad 199,039 \quad 320,569,314,330 \quad 301,257 \quad 176,639 \quad 171,219$ $1912-1913 \quad 41,335171,788 \quad 636,626 \quad 464,450 \quad 223,096 \quad 201,154 \quad 193,846$ Yearly average

for 10 yrs. $94,053,223,780 \quad 427,858 \quad 373,551 \quad 210,877 \quad 157,362 \quad 134,506$ 
Table III (cont'a).

Wonthly and Yearly Heceipts of Apples in New Yorls City.

(In Barrels)

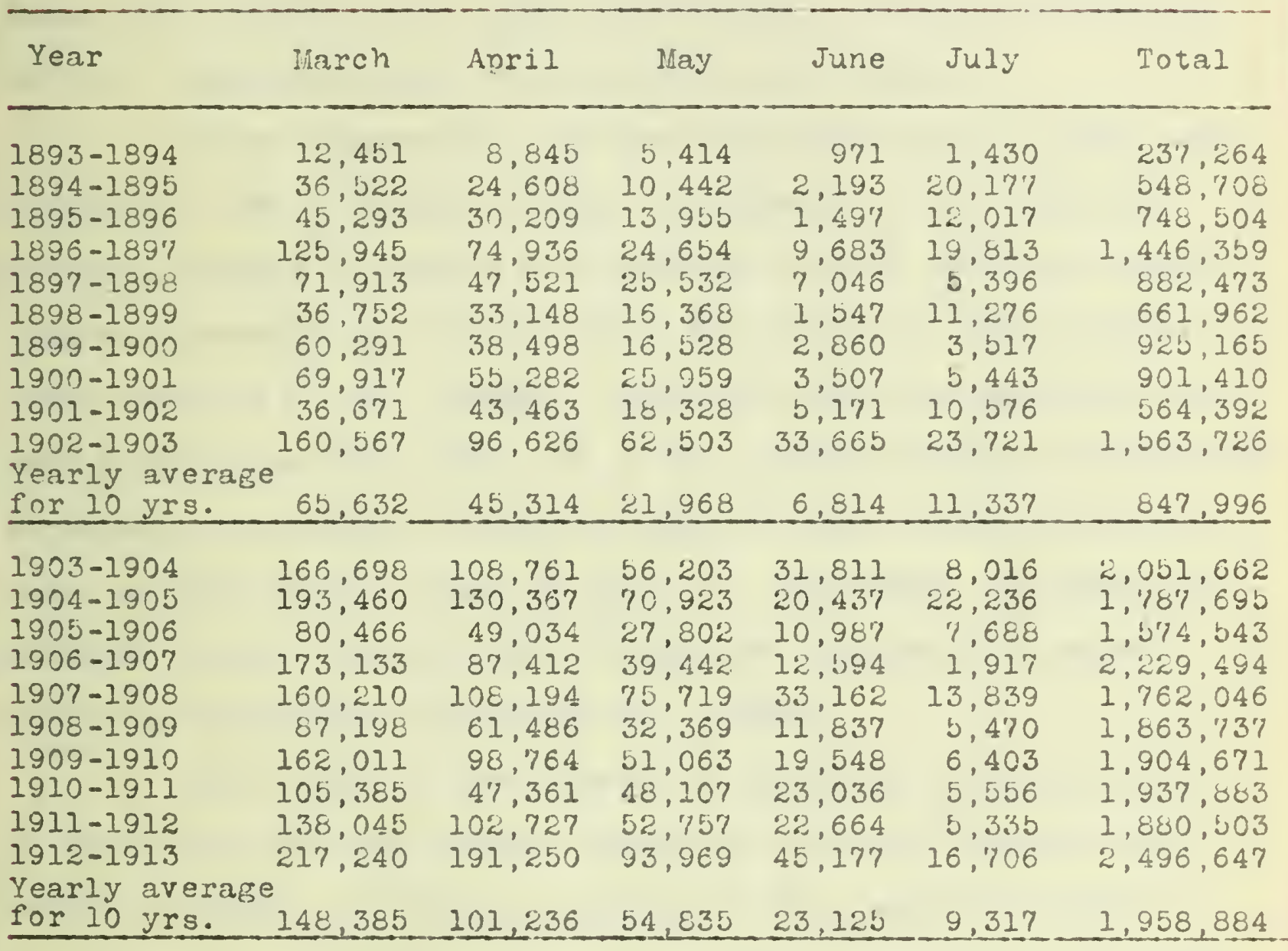



Using the average for the ten years from 1893 to 1903 , we find an average shipment for the three months of september, october, and November of 433,556 barrels, which leaves only 414,440 barrels to be shipped during the remsining nine months of the year. Using the average from 1903 to 1913. we find the average shipment for these three months to be 1,025.189 barrels, leaving only 933,686 barrels distributed over the remaining nine months.

These figures for the New York market are the only ones obtainable, but it would be rather phenomenal if the habits of New York growers in regard to disposing of their fruit at harvest time were materially different from the habits of apple growers in other sections of the country. In fact (though no exact data have been obtained on this point) 1t is the general opinion that growers throughout the country dispose of most of their fruit at harvest time, as they have no place to hold it. Therefore, it seems permissible to use these New York figures as representing general marketing conditions throughout the country.

This habit of the growers of throwing the greater part of their crop onto the market during the late fall causes difficulties to arise. There is a period of over supply followed by more or less of a shortage of apples during the remainder of the year. This maevenness in aistribution throughout the year causes relatively low prices to prevail at the time when the growers are disposing of the greater part of their crops. These low prices are a direct result of the temporary oversupply on the market, and they put the growers at a disadvantage; especially those growers who have no suitable place to store and hold their fruit. With 

over half of the apples disposed of in three months, the prices can not, of course, be satisfactory. The unevenness of distribution also decreases consumption. One might think that if the prices received were as a whole lowered, the consumption would be increased. However for the greatest use of any article, an even supply over long periods is required rather than a fluctuating supply.

Another difficulty which rises from the marketing of so much fruit in so short a time is the inability of the distributive machinery of the country to handle it efficiently. This results in considerable deterioration and loss. All through the marketing process delays occur. Trouble is experienced in securing cars, and even when they are promised, they ray not urrive as expected. In such a case, the fruit waits in the heat (if the weather is at all warm) at the station or at the packing shed, for it would hardly pay to store it when the cars are expected at any time. Usually there is no fit place to store it anyway. Even after the fruit is started rolling the delays are not over. In the confusion of the harvest season it may lie on a side track for several days, vaiting to be shifted from one railroad line to another; or the consignee may be so rushed that the fruit will have to lie on the tracks for a day or two even after it has reached its destination. The conditions surrounding the fruit during this time, if the weather is warm, are ideal for rapid ripening and deterioration. Waiting in the heat for the cars causes the Iife history of the fruit to advance rapidy. but much worse conditions are found in the cars. The hot, close, moist air in adation to ripening the fruit rapidly, is very favorable to the spread of disease As a result much of the fruit when 

It reaches the market is in poorer condition than what was left on the ground in the orchard. The poor quality of tris fruit on the market makes it act as a drug, decreasing the consumption of apples and cutting down the prices received for them.

The difficulties mentioned above would be largely overcome by the cold storage of consiaerable quantities of apples by the growers. Shipments would then be more evenly distributed throughout the year, and the raliroads and commission men would be better able to hande them. The fruit being less delayed in transit would arrive on the market in better condition, even when it was shipped during the warmer months; while that which was held in cold storage during the warm seacon and shipped during cold weather would be much superior to that which at present is taken out of common storage for winter sale, or to that which is held in the store rooms of brokers after a railroad shipment in warm weather. This added quality, togetrer with the more even supply on the market, would lead to an increased consumption, and would make the apple better able to compete with such long season, tropical fruits as the banana anà orange.

By holding fruit in cold storage better prices may be secured. Table IV (after L. b. Knapp) $(20, b)$ gives the average prices per barrel by months, for apples in New York; the table covering a period of twenty years. 


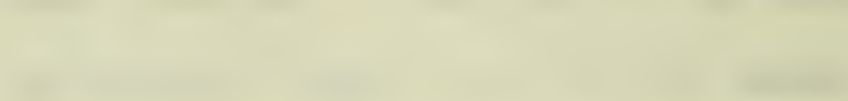


lable IV

Average Prices per Barrel of Apples in New York by Honths for Iwenty Years.

Year

Aug. Sept. Oct. Nov. Dec. Jan. Jeb. Mar. Apr..iay

june

$1893-1894 \$ 2.13 \$ 2.45 \$ 2.65 \$ 3.10 \$ 3.88 \$ 4.65 \$ 5.10 \$ 4.37 \$ 5.00 \$ 4.94$

$1894-1895$

1.831 .952 .172$.

2.34

2.58

3.00

3.84

3.694 .00

3.52

$1895-1896$

$\begin{array}{llll}1.56 & 1.59 & 1.99 & 2.13\end{array}$

2.28

2.30

2.64

2.95

3.19

3.16

\$3.25

$1897-1898$

$\begin{array}{ll}1.49 & 1.32 \\ 1.98 & 2.11\end{array}$

2.54

2.99

1.401 .531 .56

2.22

$1898-1899$

2.13

32.27

3.48

3.93

3.27

3.23

$3.16 \quad 3.08$

$1899-1900$

1.691 .811 .78

2.05

2.51

4.12

4.00

4.614 .33

$1900-1901$

1.63

¿. 32

2.70

2.74

2.31

$3.38 \quad 4.19$

$\begin{array}{lllll}3.08 & 3.23 & 3.80 & 4.45 & 4.10\end{array}$

2.59

3.21

3.23

3.36

$1902-1903$

$2.001 .72 \quad 1.991 .7 \%$

1.70

2.56

¿. 35

3.08

3.87

2.60

3.26

3.92

4.07

3.52

3.69

2.89

$1903-1904$

$2.382 .02 \quad 2.18$

2.42

2.36

2.40

352.37

2.37

2.50

2.66

3.72

3.47

$1905-1906$

2.151 .85

2.90

3.32

3.53

2.22

2.34

2.072 .66

$1906-1907$

2.67

2.482 .34

2.38

2.18

3.50

4.51

2.41

2.20

5.24

4.14

3.37

$1907-1908$

2.912 .94

3.06

2.95

2.26

$2 . \overline{8} 0$

4.775 .10

5.23

4.32

3.37

$1908-1909$

$\begin{array}{lll}2.93 & 2.59 & 2.75\end{array}$

3.00

3.58

3.08

3.71

3.82

3.94

3.05

2.56

2.55

3.31

5.48

5.64

$1909-1910$

3.15

3.31

3.04

3.27

3.20

4.11

4.33

3.043 .33

4.50

1.93

$\begin{array}{lllllll}3.17 & 3.27 & 3.28 & 3.40 & 3.37\end{array}$

3.00

3.23

$4.25 \quad 4.29$

3.58

4.93

$1910-1911$

2.34

2.222 .51

3.77

4.19

$3.10 \quad 3.14$

4.81

3.88

$1911-1912$

2.06

2.512 .63 .2 .59

2.87

2.66

$4.48 \quad 4.85$

3.16

4.33

3.11

Averages for period

$\begin{array}{llllllllllll}1893 & \text { to } & 19031.96 & 2.05 & 2.20 & 2.54 & 2.79 & 2.91 & 3.19 & 3.30 & 3.56\end{array}$

2.672 .59

2.52

2.78

2.83

2.97

3.33

3.40

3.56

3.52

4.09

4.04

3.42

3.96

3.92

During the last ten years show in this table, the average price for the three months of greatest shipment (September, October, and November) ranges from $\$ 2.59$ per barrel in september to \$2.78 per barrel in November. By the end of the commercial storage season (the last of larch or the first of April) the averatge price has risen to $\$ 3.40$ or $\$ 3.35$. At a cost of $\$ 0.50$ per barrel for storage, It mould have been a paying practice, during this ten year period, to store for sale in February, March, or April. Storage would not only have paid the storer, but would have helped the grower who 

did not store by keeping the market steadier. The Greatest airect benefits to the apple producer probably come through the prompt withorawal from market at harvest time of a large part of the best fruit. In this way prices of good fruit are less likely to be depreseed, and the average price of good apples is uncoubtedly higher than would have been possible without refrigeration. However, the consumer gets fruit which is in so much more perfect condition that he is more than satisfied to pay the slightly higher price, and there is so much legs waste that he gets more for his money.

Food conservitionists are inclined to attribute the loss of much good fruit to defects in existing marketing systerns and to the failure of orcharaists to avail themselves fully of cola storage as a means of keeping fruit to the seasor of scarcity and high prices.

Cold storage coes not, as so many belleve, injure the quality of apples or other fruits, nor does it recuce their value for food. The apple is a livine, breathing organism. In its respiration it takes in oxygen and gives off carbon àioxide and water. At the same time there are changes and losses in the constituents of the fruit; chemical actions take place which are entirely indepencent of disease anc decay. These changes have been show to be mainly a transformation of starch into cane sugar in the first stage after picking; next, a changing of this sugar into invert sugar; and finally, a slow decrease in the total quantity of sugars. At the sane time, there is from the first a slow aecrease in the amount of acid, there being most acid in the unripe fruit $(14, a)$. If apples are held until these changes are complete, the result is a fruit of poor quality, dry, mealy, tasteless, and perhaps witherea 

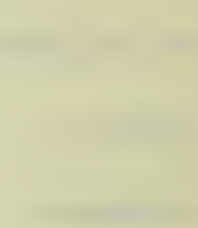

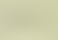

$+2$

+

- 
iruits such as winter apples and pears are not in a fit condition for consurption when picked and stored. They rnust pass through some of the ripening processes outlined above to develop proper maturity. In cold storage they pass through jugt the same stages in ripening and deterioration as they would in cellar storage, but the stages pass more slowly. By proper handing of apples in cold storage, so as to control this ripening process, the highest quality may be developed.

Cold storage preserves fruit by slowing dom its life processes. Low temperatures hinder the changes outlined above, while higher temperatures hasten them. laking the amount of carbon dioxide given off as a measure of the speed of the reaction, it has been found that changes of composition take place irom four to six times as fast at summer temperatures and from two to three times as fast at cellar temperatures as at cold storage temperatures. However, the life processes can not be stopped entirely even at the lowest temperature at wich it is safe to store fruit. Apples can not be kept indefinitely but keep about twice as long in cold storage as in cellar storage.

Another important way in which cold preserves fruit is by slowing down the IIfe processes of fungi which attack it. The three fungi causing most of the apple rots are sphaeropsis malorum (black rot), Glomerella rufomaculans (bitter rot), anc Penicillium glaucum (soft rot) $(13, b)$. The development and spread of these fungi is favored by heat and moisture. Cold storage temperatures retard their development but can not stop it entirely. 

In an experiment by the New Hampshire Station (13,b), apples were stored both at the station and at a cornmercial cold storage plant in Boston. During the first year, the temperature in the station storage room stood at 40 degrees Fahrenheit through most of the winter but rose to bo degrees in April. At the Boston storage plant, a temperature of 34 degrees was maintainea throughout the year. The experiment showed considerably less decay in the lot of frult held in cola storage. By June 1 , only $b$ per cent of the apples held at the station were free from decay while rore than 50 per cent of those held at Boston were sound.

During the second year the temperature in the station storage room ranged as follovs: from the beginning of Noverber to the midale of December, 45 degrees Fahrenheit; from the midale of December to the midale of March, 40 degrees; from the micide of liarch to the Midde of April, 45 degrees; from the midale of April to the middle of liay, 45 to 50 degrees; and from the midale of Nay to the first of July, 50 to 65 degrees. The Boston storage held the temperature of the previous season, 35 degrees. At intervals through the season, boxes mere removed from storage and examined. By January there was a slight diflerence in the way that the two lots of fruit had keot, this difference being in favor of cold storage. Ey Narch 15 this difference amounted to 35 per cent anc by June to 69 per cent. "In general it may be said that cold storage is the most practical method of controlling the rots which we at present have" $(23, b)$.

Cold storage rooms in different experiments have been 

maintainea at temperatures from 42 to 32 degrees wahrenheit. The results in all cases have been in favor of the lower ternperature. Iover temperatures not only keep the fruit longer by slowing dom to a greater extent the ripening process and the spreac of fungus diseases, but also allow the aevelopment of the highest quality, aroma, and flavor.

In an experiment at the Nichigan Agricultural College $(4, b)$. Baldvin apples rere held at $3 v$ and at 42 aegrees bahrenheit. Hy liay 22 those stored at the higher temperature vere worthless, while only 2 per cent of those held at 35 ciegrees had spoilca. An experiment by the Unitec States Jepartment of Agriculture (1b,a) showed very similar results. Fruit hela at temperatures of 36 ind 40 degrees ripened and deteriorated more rapidy, both in storage and after removal from storage, than dia that hela at 32 degrees. Because fruit mich is held at 31 or 32 degrees keeps longer than that held at 35 or 36 degrees, Cooper $(1, b)$ recommends that fruit which is to remain in storage for only a short time and which should rinen somewhat before being renoved, we held at the higher temperature.

A temperature of 31 degrees should be consiaered critical. Belor this it is unsafe to store apples. Apples are sometimes frozen in cold storage, but this does not necessarilj injure ther. In freezing, the water in the cells is withdram and frozen in the intercellular spaces. If the fruit is thaved slowly and the freezing has not been too severe, the cells may regain the water Without injury ana resume their living functions. If freezing is too severe, however, the tissues are forced apart by the formation 
of ice in the intercellular spaces and the fruit breaks down quickly Absolute cleanliness is necessary in a storage. No matter can be allowed to accumulate which gives off offensive ociorg. Noreover, a room shoula be used for the storage of only one kind or product. For example, apples should not be stored in the sane room with cabbage or cheese for the fruit would absorb the odorg of these products. To keep the air of a storage house clean and sweet, there must be ventilation. In a storage which is cooled by circulatine air much of the odor may be removed by freezing out the moisture from the air. From time to time, hovever, fresh air must be introduced. This is usually done whenever the temperature out of doors drops to about the sare point that is maintained in the storage. odors are absorbed rapialy by varn fruit just after it enters the storage. As the fruit cools ancits respiration becomes slower, it absorbs them less rapidy. Hor this reason, rapia cooling of fruit after it enters storage tends to cevelop its highest quality. The keeping quality of apples varies greatly with ailferent varieties. The cherical changes in summer and early vinter varieties take place more rapidy than in late vinter kinds. "'hey. therefore, ripen and deteriorate more quickly, and as a rule, are not so valuatle in cola storage. As a rule, courser, drier sorts such as the Ben Davis keep better than finer grained and better quality fruit such as the Jonathan.

The keepine quality of apples also varies with the cultural, soil, and climatic conditions under which they are grovm. Anything which keeps the tree in vigorous growth and wich keepg it groving late in the fall, aevelops large apples which are late 

in maturing but which ripen and deteriorate very quicily in gtorase. Large apples from rapidly growing, young treeg are less valuable for storage than medium sized, mature, bright colored, but firm fruit from older, more slowly growing trees. Apples from older trees growm on rich, heavy soil where frequent cultivation is given, where nitrogenious cover crops have been turned uncier year after year, and where there is plenty of rain, behave rnuch the same as those from young trees. Lack of pruning, by cutting out sunlight, may keep the fruit too green for the best results. These difficulties, where they exist, may be overcone by severe pruning and by seeding down the orchard for a time. Then only meaium sized bright colored fruit is selected for storage, there is little cifference between apples grom in cultivated and in sod orchards. Not only do overgrom, immature apoles keep poorly, but apples which are grown in rather dry, sandy orchards where the apples mature relatively early, have only a short storage season.

The proper maturity of fruit at the time of picking and storing is very important. In recent years there has been a tendency to pick apples earlier than formerly. Ihis has been cone partly to avold the congestion and car shortage of harvest time, and partly because of a belicf that hichly colored, mature apples are less able to stand the abuses of pickine, packing, and shipping than are hard, green ones. It is not usually the case, hovever, that the immature apples keep better. The speed of ripening varies with the degree of maturity of the fruit when picked, and the less mature apple reaches the end of its life as quickly as, or even sooner than, the more rnature fruit. Cooper $(4, b)$ reports an 
experiment in which overerown lompkins King anci sutton apples from young trees kept better when only one half or two thirds colored than when highly colored. However, apples from older trees have in all cases show better keeping quality when fully grow anc. highly colored, but still firm, than when unciercoloreu. In an Iowa experiment $(1, a)$ hald, firm, well colored Northwestern Greenings remained in prime concition for a month longer than those poorly colored and prematurely picked.

On the other hand, if apples are not picked until overripe, they are already near the end of their life and will weteriorate quickly if not stored immediately in a low temperature. In an experiment with spies at the lichigan Agricultural college $(4, b)$, the first lot was picked and stored when fully maturea and vell colored, but perfectly firm. The second lot was taken from the same trees two weeks later. By liay 22 only 18 per cent of the first lot were decayed as contrasted with 62 per cent of the second. A number of the late varieties of apples may be picked when they are beginning to mellow and will keep in prime condition for months if they are handled carefully and stored immediately at a temperature of 31 or 32 degrees. lature fruit not only keeps longer in storage, but is also superior in flavor and texture, retains its plumpness better, and is more attractive to the purchaser.

Apples for storage must be carefully handlea during the operations of pickine, grading, and packing to prevent bruising or breaking the skin of the frult. They must also be carefully graded so as to select only sound, mature, medium sized, firm fruit. It pays to store only perfect apples. Whe contents of a 
package may be injured by the spread of a fungus disease from only one or two imperfect apples. Rots gain entrance to the fruit easily around Form holes, through scab spots, or wherever the skin is bruised or broken by rough handing or by nails protruding through the container. It is therefore essential that such injuries to fruits be reauced to a minimum by care in growing, grading, and packing the crop. All of the investigations of the Jepartrent of Agriculiure emphasize the fundamental importance of well from, carefully handled fruit for successful storage operations.

The style and size of the package and the method of packing have considerable influence upon the keeving quality of apples. A small package is especially useful when storing early, quickly maturing varieties, and is most important in the hottest weather. With a barrel the fruit does not cool dow uniformly, and the apples near the center of it may continue to ripen rapidy for some time. With a small container such as the bushel box, the fruit cools dow more quickly and the ripening continues more evenly throughout the package. The, Iowa txperiment Station carried on an experiment $(1, a)$ to determine what influence the kind of package and the wrapping of fruit has upon the speed with which the fruit at the center of the package cools down. The data in Table $\mathrm{V}$ show the results obtained. 

Table V.

Effect of Wrapping and of Type of Package Upon the speed of Cooling of Apples. Package How Packed age.

Drop in Temperature of

Drop in Temperature of Air at Center of PackFruit at center of Package.

Temperature Time in Drop

Temperature Tine in Irop. Storage

Slat Crate Unwrapped $41^{\circ} \mathrm{F} \quad 1$ day, $14 \mathrm{hr} .43 .5^{\circ} \mathrm{F} I$ day, $10 \mathrm{hr}$. Bushel Box " " 43

Barrel

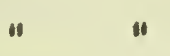

43

2 " 18 "

42.5

2 " 10 "

slat Crate "rapped

41.5

3 " $2 "$

39

43.5

2 " 18 "

44

3 "

$2 "$

Bushel Box

43.5

2 " $22 "$

43

2 " 18 "

Barrel

" 37

3 "2

37

$2 \quad$ " $22 "$

3

\section{(1)}

1.

Though fruit in a slat crate cools dovn most quickly, this type of package is suitable only in cases of short storage. Fruit in a crate ghrivels and loses its attractiveness much more quickly than in a closed package. There is also nore danger of bruiging the fruit against the edges of the slats. For these reasons ventilated containers should not be used where long storage is intended.

At present the bushel box seems to be the most satisfactory container. In it the fruit cools quickly and is protected from the excessive evaporation show in ventilated crates. Moreover, fruit can be held in storage in the bushel box until riper than it could be held in a barrel. As soon as apples in barrels begin to nellow, they must be sold to prevent bruising by their ow weight, but apples in boxes may sometimes be carried for several weeks longer. 

Though wrappers as shown in the above table, delay sightIy the cooling of fruit, they are nore beneficial in other vays than they are harmful in this. They prevent nuch of the bruising of fruit due to improper packing, and they prevent its withering due to excessive transpiration. For these purposes a double wrapper has proven most efficient. A satisfactory combination consists of an absorbant, unprinted, nevspaper next the fruit, with a more impervious parafin wrapper outgide. Arapping also prevents the spread of decay through the package. Each apple is isolated from the others by wrappers, and in this vay is protectea from any fungus spores which may develop upon a chance diseased fruit. Wrappine: retards somevhat the ripening of fruit; and this in conjunction with the decay prevention holas wrapped fruit in prime condition several weeks longer than unwrappea fruit can be held. In commercial practice the wrapping of hard, late varieties is of little inportance, but wrapping has a distinct auvantage in extending the life of tencied varieties and in preserving their bright, attractive appearance and firmness.

Delay in the storage of apples after picking seriously injures their keeping qualities, especially if this delay comes during hot, noist weather. The delay is nore serious with quickly maturing varieties than with hard, late, winter sorts. An apple, after its growth is stopped by picking, ripens rnore rapialy than When on the tree, growing and ripening at the same time. The speed of ripening also varies with the temperature, being from four to six times as fast at sumer temperatures as at cold storage temperature. The ripening should be slowed dom by storing as quickly as 
possible, as ripening is at the expense of cell contents and brings the fruit nearer the end of its life. Heat and moisture also favor the rapid spread of fungus diseases through piles of picked fruit. These diseases develop raplaly and cause much danage to fruit which becomes heated after picking.

The importance of Immediate storage in warm moist weather is show by an experiment which vas carried on in New York in 1902 $(15, b)$. During the latter half of september the temperature in eastern New York averaged about 62 degrees Fahrenheit, while there was about 84 degrees of humidity. Luring the firgt half of october the average temperature fell to 53 degrees and the humidity to 80 degrees. Rhode Island Greening, lomplins King, and Sutton apples picked september 15 and stored within three days were firm until the following Varch, but fruit from the sane trees which was not stored until two weeks after plcking mas badly scalded or aecayea by the first of January. The commercial value of these varietieg was reduced from 40 to 70 per cent by this delay. Apples from the same trees picked October 5 were less injured by delay in storing.

A serious trouble in storage, with which the owner must reckon, is apple scald. I'his disease causes a broming of the skin which injures considerably the market value of the fruit. It does not, however, affect the flesh, except that the apple may break down more quickly.than a perfect one. "The disease as at present understood is a physiological disturbance not in any way connected with the action of parasitic or saprophytic organisms such as molds or bacteria. Briefly, it is the rixing of the cell contents, or the premature death of the cells and their browning due to oxidation 
through the influence of normal oxidizing ferments of the cells" $(15, b)$. The disease is not contaginus but seems to be closely connected with the ripenine of the fruit atter picking. It is most serious as the fruit approaches the end of its life.

Though scald is worge with packed fruit as it advances in ripeness, it is not prevented by picing immature fruit. The scald first appears on the green side of an apple and is worse on poorly colored lots. Highly colored, mature, but firm apples are least affected by the trouble. Pable VI (after G. F. Powell) shows the influence of maturity upon scalding.

\section{Table VI.}

Per Cent of Scald Developing on liature and Immature Apoles.

\begin{tabular}{|c|c|c|c|}
\hline Variety & $\begin{array}{l}\text { Locality } \\
\text { Where Grown }\end{array}$ & $\begin{array}{l}\text { liature, vell } \\
\text { colored truit }\end{array}$ & $\begin{array}{l}\text { Immatur } \\
\text { Iy Colo } \\
\text { Iruit }\end{array}$ \\
\hline aldwin & New York & 3.1 & $29 \cdot 2$ \\
\hline en Davis & Illinois & 2.6 & $1 り .8$ \\
\hline " 1 & Virginia & 13.1 & 41.6 \\
\hline hode Island Greening & Iew York & 25.4 & 43.4 \\
\hline inesap & IlIinois & 0.2 & 31.8 \\
\hline ellow Newton & Virginia & 2.3 & 9.4 \\
\hline ork Imperial & Virginia & 2.0 & 18.2 \\
\hline Average & & 6.9 & 27.0 \\
\hline
\end{tabular}



From these facts it may be seen that late picking, or the use of cultural methods mich will insure early maturity and high color, vill decrease scald. Cultural methods which have these effects are heavy pruning to let light into the tree, and the use of a cover crop to ripen off the tree early in the fall.

Ripening during any delay in storing increases the susceptibility of apples to scald. Scald often develops seriously when storage is delayed in hot weather. In Nem York in $1902(4, b)$, Rhode Island Greenings which were picked September 15 and stored within three days kept firm and free from scald until the following Narch; while those whose storage was delayed two weeks at an average temperature of 62 degrees mere one-third scalded by the first of Gebruary. Similar results mere reported by $\mathrm{S}$. A. Beach in Iowa Bulletin $108(1, a)$.

Different varieties of apples vary greatly in their susceptibility to scald and in the time at which the trouble attacks them. Some storage men state that greenish or yellow varieties are affected rorse than reo ones. However, this idea is not borne out in data presented by G. H. Powell $(15, b)$. Of the thirteen rea varieties reported by him, five were affected seriously; four, often seriously; tvo, sometimes seriously; and two, but slightly. of these varieties, one was affected in early vinter; seven, in midwinter; one, after midwinter; and four, late in the season. of the seven greenish or yellow varieties reported, four were seriously anc three slightly affected; the trouble attackine one in early winter, three in midwinter, and three late in the season. Not 
enough difference is shown between these two groupings for anyone to draw the conclision that either color is more susceptible. The susceptiblity of a variety to scald does not seer to depend upon its physical characteristics. Yellow Nevton, a moderatcly fine grainea, juicy, yellov varicty, is but slightly affected late in the season; while snith cider, a moderately fine grinea, juicy, red apple, is seriously attacked in early winter. villow, a coarse, iuicy, red apple, is affected but slightly, late in the season; while crimes, a noderately coarse, moderately juicy, yellow variety, is attacked seriously in early winter.

The development of scald upon a lot of apples comes suadenly. Table VII (after PoweII) $(15, b)$, shows the time at which scald ceveloped on Baldwirs.

\section{lable VII.}

lime of Development of scald on Baldwin Apples.

\begin{tabular}{lc} 
Dated Exarined & Per cent of Scald \\
Jan. 29, 1903 & 0 \\
Feb. 21, 1903 & 0 \\
Iiar. 20, 1903 & 20 \\
Apr. 21, 1903 & 23 \\
\hline
\end{tabular}

This table shows clearly the abruptness vith wich scala attacks a lot of fruit. A variety should be removed from storage before the time that it nornally begins to scald, and only those varieties which do not scald should ve held until late in the season. 

The vrapping of apples has sometimes been claimea to aecrease scald. However, though wrapping sometimes retards the trouble slightly, scald is often as severe or more severe with wrapped than with unwrapped fruit. When an increase of scald occurs it is attributed to the collection inside of the mrapper of carion aloxide given off by the fruit. Good ventilation in conjunction with refrieeration is essential for successful storage.

The temperature at winich apples are stored influences considerably the development of scald. Iower temperatures retard ripening to a greater degree, and also retard most the appearance of scald. Scald after the removal of apples from storage is increas ed by higher outside temperatures and by greater ripeness of the fruit at the time of removal, but is decreased by a higher moisture content of the air. Table VIII (after G. H. Povell) (1b,b) ghows the effect of removing apples into different temperatures.

\section{iable VIII}

Scald Development upon Apples Fiemoveà into Different Temperatures

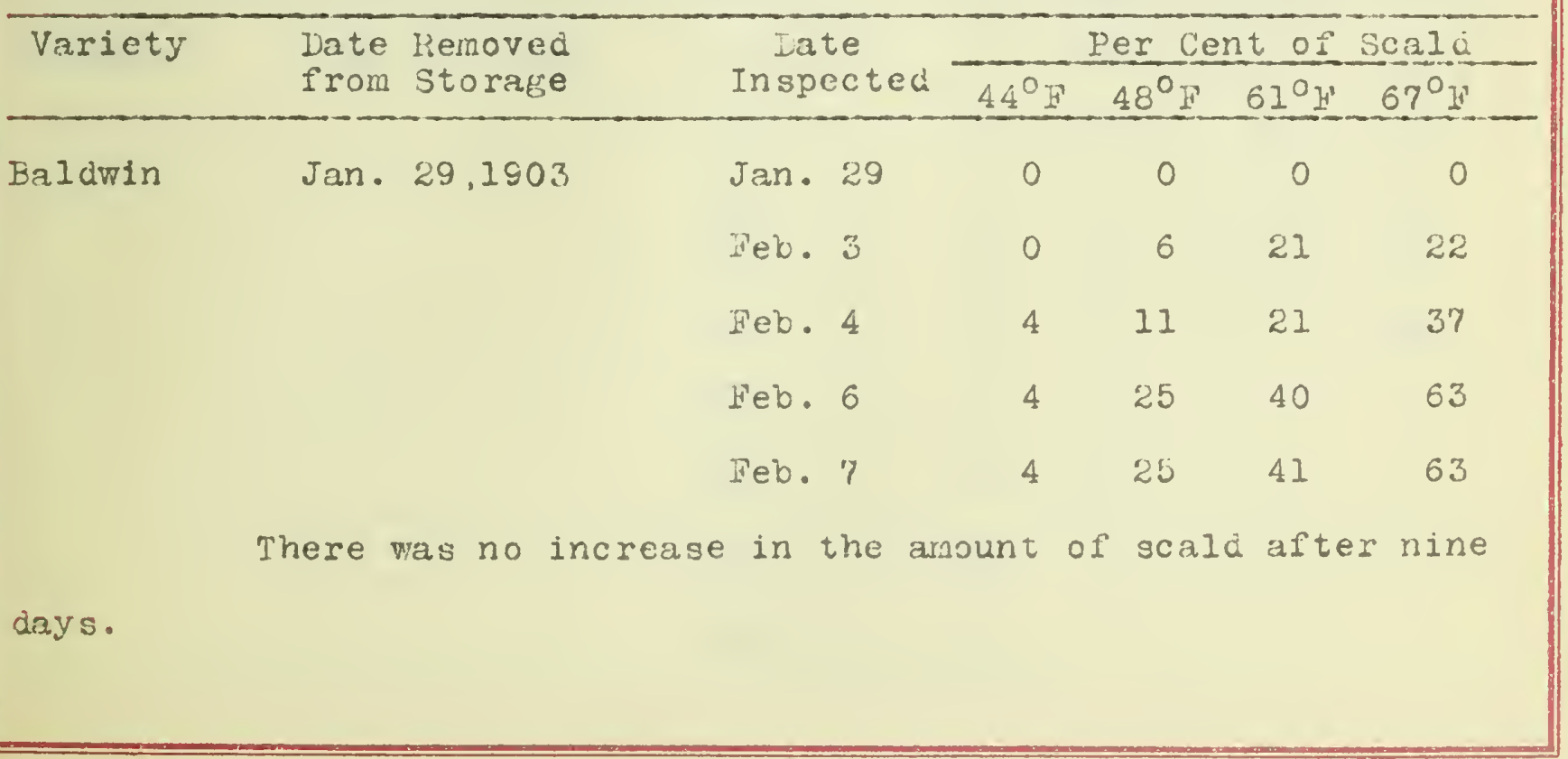


The fruit storer shoula not only aim to remove the fruit before the normal season of scald, but also to holu the apples, after removal, in the lowest possible temperature.

Fruit which has been taken from cola storage is thought by many dealers to break cown more quickly than cellar storea fruit. When this appears to be the case it is probable that the fruit was hela in cold storage until over ripe. "hen removed to a wam temperature it vould then complete its deterioration rather quickly. It is not probable that cold storage apples break dom any more quickily than other apples of the same degree of ripeness when held at the same outside temperature. The temperature into which the apples are taken is, of courge, a very important ractor in wetermining the speed of deterioration. lable IX (afier G. H. Fowell) (Ib, D) shows the effect of removing Balumin apples into aifferent temperatures.

\section{Table IX.}

Decay Development upon Apples Rernoved into lifferent Temperatures.

\begin{tabular}{|c|c|c|c|c|c|c|c|}
\hline \multirow[t]{2}{*}{ Variety } & \multirow{2}{*}{$\begin{array}{l}\text { Date } \\
\text { from }\end{array}$} & \multirow{2}{*}{$\begin{array}{l}\text { Removed } \\
\text { Storage }\end{array}$} & \multirow{2}{*}{$\begin{array}{c}\text { Date } \\
\text { Ingpected }\end{array}$} & \multicolumn{4}{|c|}{ per Cent of Rot } \\
\hline & & & & $44^{\circ} \mathrm{F}$ & $48^{\circ} \mathrm{F}$ & $61^{\circ} \mathrm{F}$ & $67^{\circ} \mathrm{E}$ \\
\hline \multirow[t]{9}{*}{ Baldwin } & $\operatorname{Jan}$ & 29,1903 & Jan. 29 & 0 & 0 & 0 & 0 \\
\hline & & & Feb. 10 & 0 & 0 & 3 & 10 \\
\hline & & & lieb. 13 & 0 & 0 & 12 & 14 \\
\hline & & & Feb. 16 & 0 & 0 & 21 & 24 \\
\hline & & & Feb. 20 & 0 & 4 & 23 & 28 \\
\hline & & & lifir. 3 & 5 & 10 & - & -- \\
\hline & & & Har. 7 & 5 & 15 & -- & -- \\
\hline & & & kiar. 24 & 20 & - & -- & -- \\
\hline & & & Apr. 6 & 36 & -- & - & -- \\
\hline
\end{tabular}


The speed of breaking cowm will also vary considerably with different varieties. Many of the best cold storage varieties are too tender for cormon storage, and shoula not be used in comparison with other varieties from common storage to ascertain the relative effects of the two storage systems upon the keeping qual1ty of fruits. Cold storage has done a great service in bringing tender varleties of high quality into commercial significance.

The cold storage business has become inportant in stabilizing the fruit industry. It stores up the temporiry oversupply at harvest time and distributes the fruit at home and abroad as it is needed. Though apple proaucers have been glower than citrous and troplcal fruit growers to avail themselves of the opportunities offered by this comparatively young industry, they are beginning to recognize the importance of colà storage in ciring for their product The arnount of apples in storage on Decernber 1 (22) has increased rapidy in the last fifteen years, rising from 1,226,900 barrels in 1900 to $5,332,157$ barrels in 2915. This growth of storage has had an important influence on the development of markets both at home and abroad. From 1890 to 1900 the average export of apples amounted to 575,548 barrels $(23)$; between 1900 and 1910 it rose to an average of 1,213,388 barrels; and between 1910 and 1915 the average export reached $1,837,138$ barrels. As the cold storage of apples becomes more firmly established the grower will feel the benefit of steadier conditions in the apple trade and of more uniform prices. The consumer will also be benefited by being able to secure apples throughout the year at more uniform prices, and by getting better fruit than that which is hela in comon storage. 

Cold storage is increasing the commercial value of many tender but otherwise desirable varieties of apples. Fornerly such varieties had to be sold soon after picking to prevent loss from decay. Early winter varieties such as the "Tealthy, Grimes Golden, Jonathan, and IfcIntosh, may now be stored until midwinter or even later, adding varieties of high quality to the list of apples obtainable during that period. In this way cold storage has increased the use of high grade varieties that formerly had to be planted in restricted quantities.

Only the best srom and best handed fruit is stored successfully. This has caused dealers, when purchasing for storage. to discrinintte against those orchardists who are careless in orchard management and in grading and packing their fruit. Ihis discrimination has led apple producers in general, to improve their methods and to turn out fruit of higher quality. This education of orcharists has been one of the most important resulis of the groming use of cold storage. 

Bibliography.

1. Beach, S. A.

a. "Cold storage of Iowa Grown Apples"

Iova sta. Bul. 108.

b. "Ner York Apples in Storage",

IT.Y. (Geneva) BuI. 248.

c. "The Apples of Ner York",

J. B. Iyon, Printers; Aibany (1905)

2. Bigelom,

"Studies on Apples",

U. S. Dept. Agx., Bur. Chern. Bul. 94.

3. Budd, J.I.

"The Comrercial Preservation of Fruit",

Irans. Iowa Hort. Soc. 28; pr. $270-272$ (1893).

4. Cooper, Nadison

a. "The Pre-Coolinfs of Truit"

Cold, 4: 10, pp. 183-189 (Aug.,1913).

b. "Practical Cola storage"

pp. 341-424, Nickerson Scoliins Co., Chicago,1914.

5. Corbett, I. C.

"Cola Storage", W. Va. Sta. Bul. "74.

6. Faville, E. E.

"Cold storage of Fruit"

Kans. Station Bul. 84.

7. Fulton, G. H.

"The cold Storage of Small iruits",

U. S. Dept. Agr.,Bur. Plant Indus. Bul. 108.

8. Glasson, E. J.

$$
\begin{aligned}
& \text { a. "Crop Conditions", } \\
& \text { An. I.B. (1914) p. } 463 . \\
& \text { b. "Crop Conditions", } \\
& \text { An. Y.B. (1915) p. } 472 .
\end{aligned}
$$

9. Gore, H. C.

\footnotetext{
"Apple Syrup and Concentrated Cider", IJ. S. Dept. Agr. Yo. (1914) p. 227.
} 

10. Greene, L.

$$
\begin{aligned}
& \text { "Cola Storage of Iowa Grown Apples", } \\
& \text { Iowa Sta. Bul. 144. }
\end{aligned}
$$

11. Hill, G. I?.

$$
\begin{aligned}
& \text { "Respiration of Pruits", } \\
& \text { N.Y. (Cornell) BuI. } 330 .
\end{aligned}
$$

12. Heubner, S. S.

$$
\begin{aligned}
& \text { a. "Crop Production" } \\
& \text { Am. Y.B. (1914) p. } 320 . \\
& \text { "Crop Production", } \\
& \text { Aro.Y.B. (1915) p. } 327 .
\end{aligned}
$$

13. Lamson, H. H.

$$
\begin{aligned}
& \text { a. "Storage of Apples", } \\
& \text { N.H. Sta. Bul.79. } \\
& \text { b. "The Cola Storage of Appleg", } \\
& \text { N.H. Sta. Bul. 93, pp. 75-81. }
\end{aligned}
$$

14. Norge, F. T.

$$
\begin{aligned}
& \text { a. "The Cold Storage of Ipples" } \\
& \text { N.I1. Sta. Eul. } 93 \text {, pp. } 81-8 \% . \\
& \text { 3. "The Respiration of Apples", } \\
& \text { N.H. Sta. Bul. 135. }
\end{aligned}
$$

15. Powell, G. H.

a. "Cold storage",

U. S. Dept. Agr., Bur. Plant Indus. Bul. 40.

b. "rhe Apple in Cola Storage",

U. 3. Dept. Agr., Bur. Plant Inalus. Bul. 48.

c. "Cola Storage Investifgations by the United 3tates Department of Agriculture", Trans. Ill. Hort. Boc., n. ser. 36; p.363 (1902)

d. "Relation of Cold Storage to Cormercial Apple Culture U. S. Dept. Agr. Yo. pp. 225-238 (1903).

16. Price, H. C.

$$
\begin{aligned}
& \text { "Cold Storage of Apples", } \\
& \text { Iowa Sta. Bul. 72. }
\end{aligned}
$$

17. Rane, I. T.

$$
\begin{aligned}
& \text { "The Cold Storage of Appleg", } \\
& \text { II. H. Sta. Bul. 93, pp. 65-74. }
\end{aligned}
$$

18. Ruddick, J. A.

"Trial Shipments of Cold Storage Apples", Deot. Dairy \& Colo Storage Com., Ottawa Canada Bul. 24. 

19. Taylor, ". A.

"The Influence of hefrigeration on the iruit

Industry", U. S. Dept. Agr. Yo. pp. 56I-b80, (1900)

20. Wilkinson, A. E.

a. "The Apple" pp. 375-383.

Ginn and Company, New York, 1915.

b. ibid, pp. $48 I-487$

21.

"Production and Prices of Apples on December 1 , by States frorn 1909 to 1915",

U.3. Dept. Agr. Yo. (1915) pp. 487,488.

22.

"Keport of Cold storage Apple Holdings", U. S. Dept. Agr., Office of Narkets and liural Organization.

23.

"Exports of Apples, 1852-1915".

U. S. Dept. AEr. Yo. (1915) p. 556. 



$$
\text { , }
$$


UWIVERETT OF ILWOW-UREANA

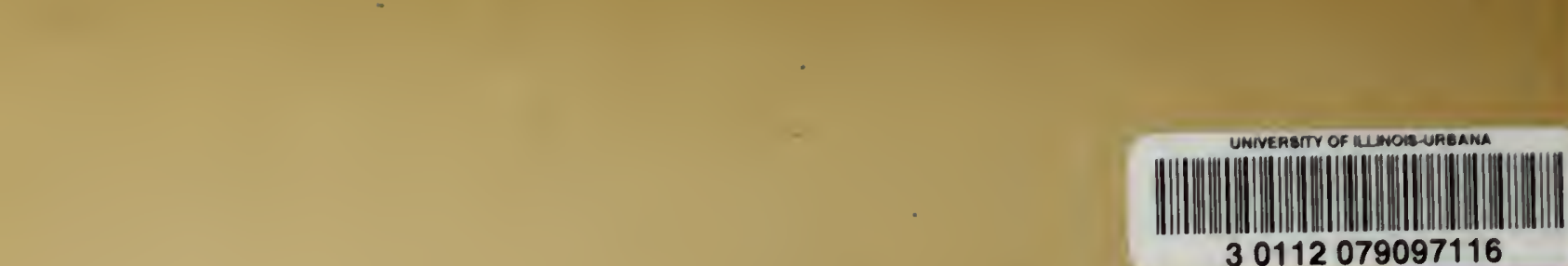

30112079097116 